\title{
frontiers
}

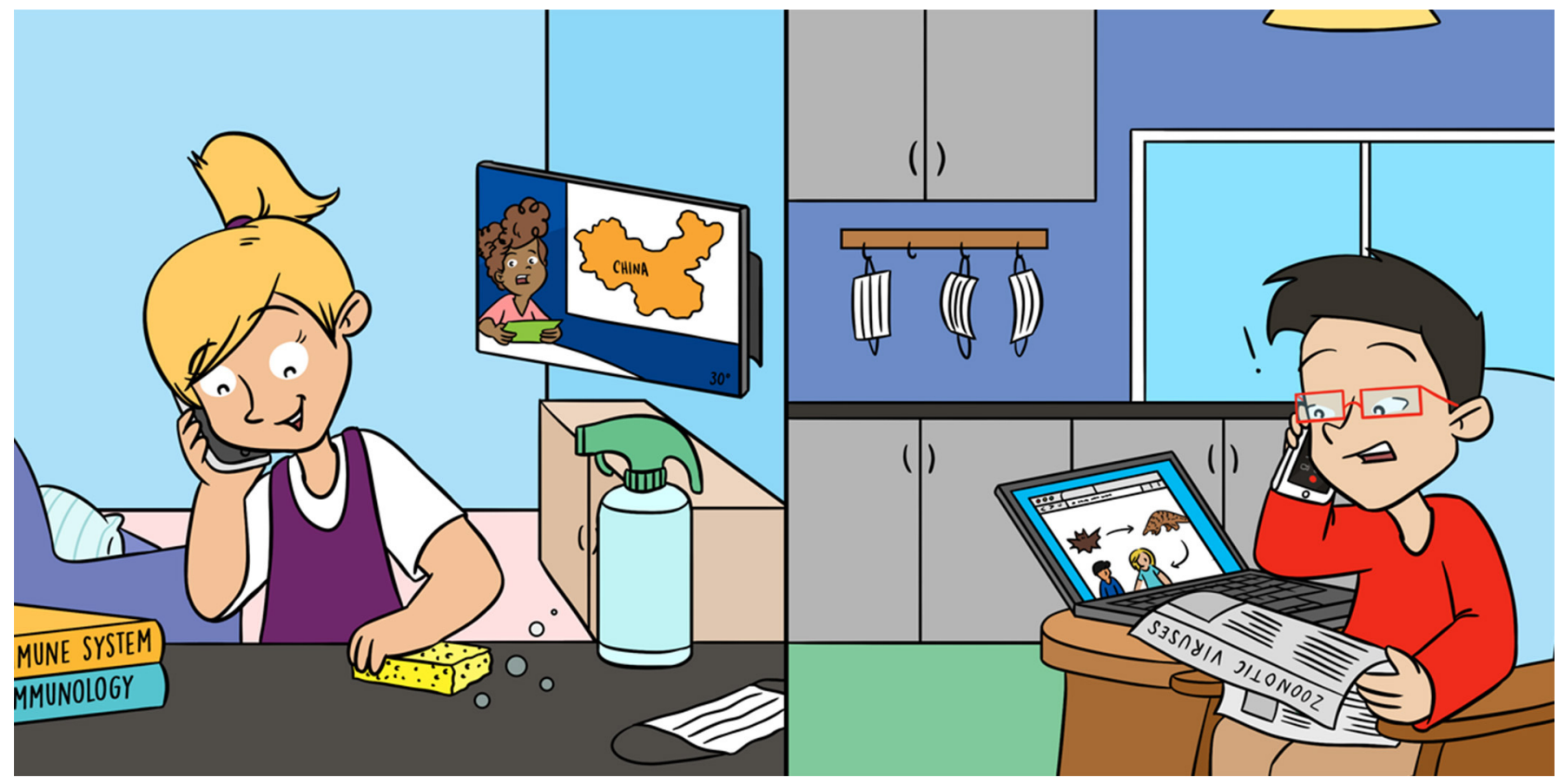

\section{COVID-19: THE NEW IMMUNE CHALLENGE}

\section{Suleman R. Sabir ${ }^{1,2}$, Emma C. Thomson ${ }^{2,3,4}$, Tomasz J. Guzik ${ }^{5,6}$, Fulvio D'Acquisto ${ }^{7}$ and Pasquale Maffia ${ }^{2,5,8^{*}}$}

${ }^{1}$ The School of Medicine, Medical Sciences and Nutrition, University of Aberdeen, Aberdeen, United Kingdom

${ }^{2}$ Institute of Infection, Immunity and Inflammation, College of Medical, Veterinary and Life Sciences, University of Glasgow, Glasgow, United Kingdom

${ }^{3}$ MRC-University of Glasgow Centre for Virus Research, Glasgow, United Kingdom

${ }^{4}$ Department of Infectious Diseases, Queen Elizabeth University Hospital, Glasgow, United Kingdom

${ }^{5}$ Institute of Cardiovascular and Medical Sciences, College of Medical, Veterinary and Life Sciences, University of Glasgow, Glasgow, United Kingdom

${ }^{6}$ Department of Internal Medicine, Jagiellonian University, Collegium Medicum, Kraków, Poland

${ }^{7}$ Department of Life Science, University of Roehampton, London, United Kingdom

${ }^{8}$ Department of Pharmacy, University of Naples Federico II, Naples, Italy

\section{YOUNG REVIEWERS:}

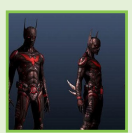

AYDEN

AGE: 12

(कILI

AGE: 9

ZOE

AGE: 8
Do you want to know more about Coronavirus infection? What has actually happened and why now? How big is the virus? How does it harm people? Where did the virus come from, and how did it spread to humans? Or maybe you want to know how your body defends itself from the virus. Well, you can find the answers to all these questions in this short article. We hope you will enjoy reading. 


\section{SARS-COV-2}

The coronavirus responsible for the disease we call COVID-19.

\section{COVID-19}

The disease caused by the SARS-CoV-2.

\section{PANDEMIC}

An infectious disease that has spread across multiple continents or worldwide.

\section{VIRAL REPLICATION}

The formation of new viruses in the infected human cell.

\section{WHAT HAS HAPPENED ALL OF SUDDEN?}

You might be at home in your PJs, maybe getting ready for your online class, and suddenly you think, "What has actually happened and why now?" You look outside and nothing really seems to have changed. The grass and trees are still there, the birds are chirping, and the sun and the moon are chasing one another as always. You cannot see the actual problem, yet your family and friends talk to one another from a distance and might even cross the road when someone comes toward them.

When you look online or listen to the news, you hear there is a new virus around, called SARS-CoV-2, which causes a disease called COVID-19, which is very dangerous and can seriously harm people. This virus is causing a pandemic, meaning that it has spread across the world. You scratch your head and wonder, "But where is it? And how many are there? I have not seen anything. How does it harm people?" In terms of numbers, viruses are probably the most represented "living thing" on the planet. There are estimated to be one hundred nonillion in total, which means 100,000,000,000,000,000,000,000,000,000,000! That is a lot of viruses to have around, considering there are only around 7.7 billion $(7,700,000,000)$ people on earth. The reason we cannot see viruses is that they range from $20 \mathrm{~nm}(0.0000008$ inches) to $400 \mathrm{~nm}$ in size. This means that viruses are normally 5,000 times smaller than a strand of hair, so they are not even visible with a normal microscope.

When you look at viruses with a powerful electron microscope, they are rather elegant due to their symmetrical structure. For SARS-CoV-2, this symmetrical shape is made even more appealing by a ring of proteins that encircles the virus like jewels on a crown. This structure is what gives the name corona (crown) virus to this family of viruses. The outer structure of a virus is called the capsid and it serves as a container for the virus' genomic material (DNA or RNA). When viruses infect our bodies, they inject their genetic material into our cells. The infected cells then become factories to produce new viruses, in a process called viral replication. These new viruses explode out of the host cell and kill the cell in the process.

In the case of SARS-CoV-2, the cells infected are those lining the upper part of the respiratory tract. As a result, when newly assembled SARS-COV-2 viruses burst out of lung cells, they are expelled into the air we breathe. Specifically, they are packaged in small bubbles of water and air that are normally expelled during breathing. These vaporized bubbles, also known as droplets, effectively become cannonballs when we sneeze and cough. These droplets can propel the virus into the air at high speed and over a great distance. It is estimated that the droplets generated from a sneeze can travel as far as 6 feet $(1.8 \mathrm{~m})$ and the large gaseous clouds produced upon sneezing can travel up to 27 feet $(8.2 \mathrm{~m})$. You might now start to realize why 
Figure 1

"Jumping" of COVID-19 from bats to humans. SARS-CoV-2, a zoonotic virus, originated in bats. It is believed to have jumped to pangolins and then to humans (created with BioRender.com).

1 https://coronavirus. jhu.edu/map.html.

\section{ZOONOTIC DISEASE}

An infectious disease caused by a pathogen that has jumped from an animal to a human.

\section{ACE-2}

The protein used by the coronavirus to invade human cells.

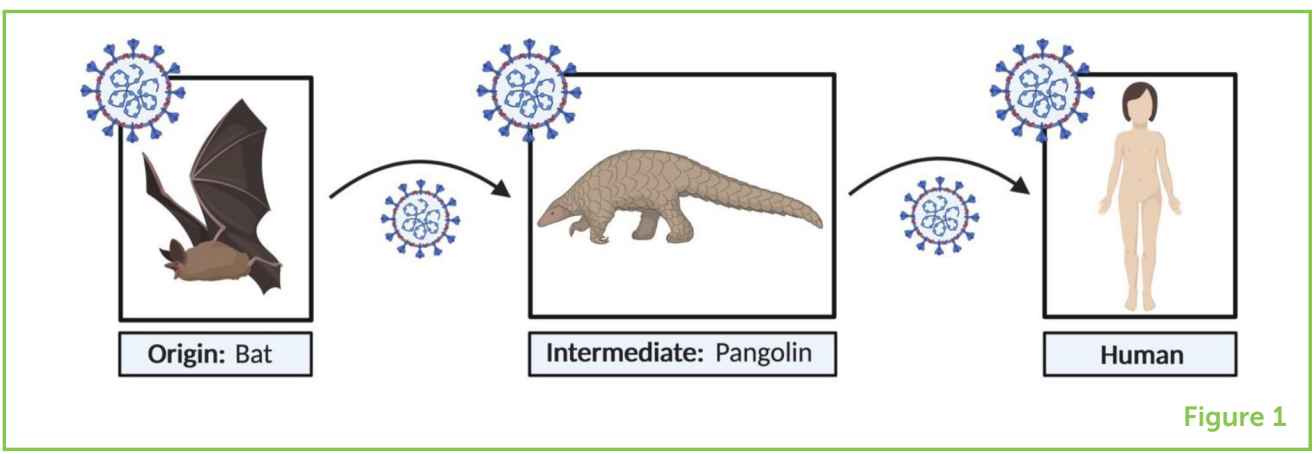

people have been talking from afar and wearing masks over their noses and mouths.

\section{EXCUSE ME, WHERE ARE YOU FROM?}

You may never have heard of coronavirus or COVID-19 before this year, and you may wonder why it has become such a hot topic in recent times. It all started in December 2019, when it was announced to the world that a new virus had been identified in Wuhan, a large city in Hubei Provence in China. Unlike other viruses, this one spread rapidly across the world and was responsible for the deaths of over 545,000 people in 6 months $^{1}$. Named SARS-CoV-2, the virus causing the disease COVID-19 continues to spread from country to country and has been the reason for many governments asking their citizens to stay at home. Having witnessed nothing on this scale in recent years, healthcare systems across the world are locked in an ongoing effort to limit the spread of the virus.

How did COVID-19 begin in China? To explain this, we need to take a step back and understand how viruses adapt to their surroundings. Viruses, in general, like to replicate only within the specific species of animals they are familiar with. However, some viruses, called zoonotic viruses, can adapt themselves to survive in different species or, as scientists often say, "jump" from one species to another. SARS-CoV-2 originally only infected bats [1], but for reasons that are not completely clear, it developed to the ability to "jump" to the pangolin (a scaly anteater) (Figure 1) [1]. These animals are popular in Chinese medicine, as both their meat and scales are used to treat a wide range of illnesses. Researchers think that after SARS-CoV-2 infected pangolins, it adapted and gained the ability to jump to other species.

How did this coronavirus become able to infect humans? When SARS-CoV-2 infects humans, it uses proteins on its surface called spike proteins, that can "hook" onto another protein found on cells lining the human upper respiratory tract, called epithelial cells. This human protein is called angiotensin converting enzyme-2 (ACE-2) (Figure 2) [2]. The docking of spike proteins with ACE-2 allows the coronavirus to firmly land on epithelial cells infecting them. 
Figure 2

The mechanism used by SARS-CoV-2 to establish infection in humans. The binding of spike proteins to ACE-2 on the surface of lung epithelial cells is essential to SARS-CoV-2 entering the body and establishing infection (created with BioRender.com).

Figure 3

Symptoms associated with SARS-CoV-2 infection. Symptoms may be mild, such as a slight cough, fever, and body aches, or more severe, including breathing difficulties and pneumonia (created with BioRender.com)
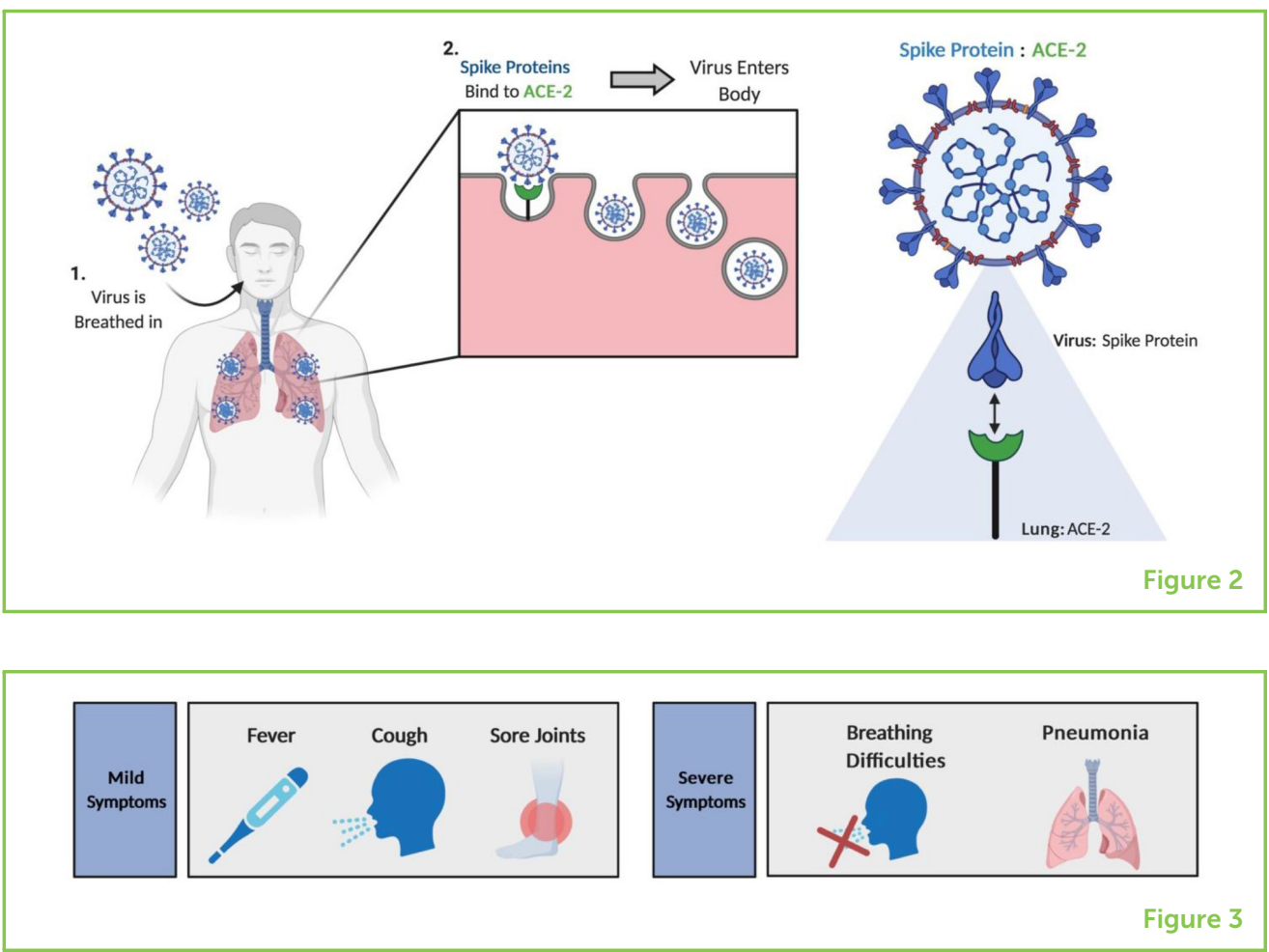

\section{HOW DOES SARS-COV-2 AFFECT HUMANS?}

Since the lungs are the main site of infection, many patients infected with SARS-CoV-2 have symptoms that are related to inflammation and sickness of the lungs. These include shortness of breath, a persistent dry cough, fever, aching muscles, and joint pains (Figure 3) [1]. These symptoms might remind you of how you feel when you have a cold, and you are right to think that COVID-19 and the common cold share some similarities; however, there are major differences. First, in some severe cases, patients infected with SARS-CoV-2 may develop a serious lung infection called pneumonia (Figure 3) [1]. This can result in the lungs becoming weak and inefficient and can cause issues with oxygenating the blood. As a result, patients may develop a condition called severe respiratory distress syndrome. Although this predominately occurs in the sickest patients, respiratory distress can result in death. Second, and probably most importantly, around $80 \%$ of people infected with SARS-CoV-2 show only very mild symptoms, or are asymptomatic, which means they show no signs of infection [1]. This virus can also be transmitted from one person to another unexpectedly well. If you put together the fact that people might be infected without knowing it and the high rate of transmission, you can begin to appreciate why COVID-19 has become a pandemic. 
Figure 4

Immune education and memory. Immune education occurs when the immune system sees a pathogen for the first time and learns about it. If the person is later infected with the same pathogen again, the immune system will remember what it learned the first time because of immune memory, so it will be able to respond quickly to eliminate the pathogen (created with BioRender.com).

\section{IMMUNE MEMORY}

The ability of the immune system to quickly and specifically recognize pathogens that the body has previously encountered.
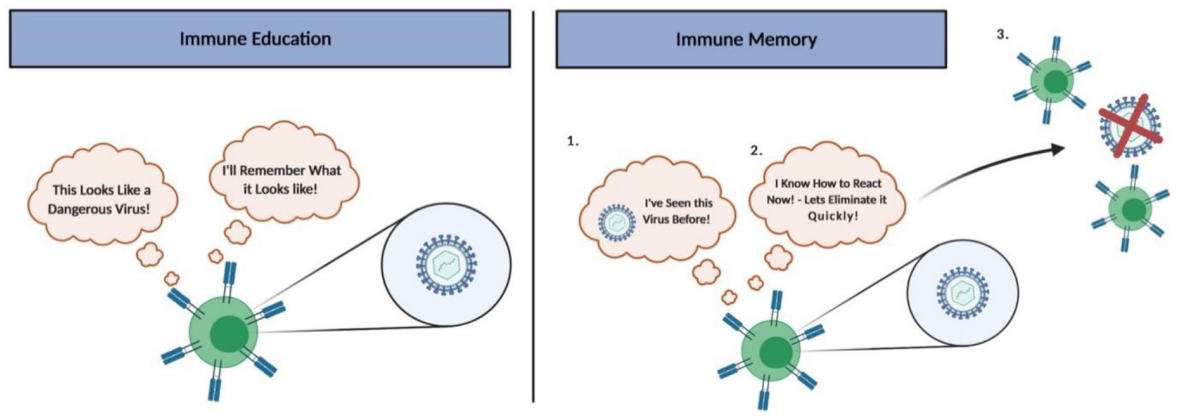

Figure 4

\section{HOW THE IMMUNE SYSTEM DEALS WITH SARS-COV-2}

As much as SARS-CoV-2 would like to hang around in our lungs and continue to replicate, our bodies are designed to prevent this from happening. This is important, because viral replication destroys epithelial cells and eventually prevents our lungs from functioning properly. To deal with SARS-CoV-2 and other invisible organisms that might infect us, the body has developed an army of cells that protect itself: the immune system (you can learn about immune cells by looking at other FYM articles, such as [3-5]). One key feature of the immune system is its ability to recognize and eliminate viruses and other pathogens when it sees them. The immune system learns to do this by being exposed to the pathogen the first time and learning everything about it. This process is called immune education (Figure 4, left). Immune education allows the body to learn the best way to fight a certain pathogen. If the body later sees the same pathogen again, it can respond in a way that is better and faster, based on what it learned the first time. This process is called immune memory (Figure 4, right).

The concepts of immune education and immune memory are the basis of vaccination. Vaccines are usually made of dead or weakened pathogens, or the important pieces of those pathogens. When a vaccine is administered, we give the immune system the chance to deal with a safe version of the pathogen and to learn from it, without risking that the pathogen can cause disease in the vaccinated person. Currently, we do not have a vaccine for SARS-CoV-2, so this is the first time that human immune systems have been exposed to it.

\section{SUMMARY}

It might feel to you like COVID-19 has changed the way we live our lives. It has affected everything about our social lives, from school, to the ability to go out to have fun or to go on holidays. However, like many other diseases in the past, we are learning a great deal about SARS-CoV-2 and how to prevent infections in the future. We will also learn new ways of interacting and socializing! For those of us who 
are not working on the frontlines in hospitals or in the lab studying the virus, it might seem like there is very little that we can do to help. However, the simple fact that you are reading this article is as important as what is currently done by doctors and scientists! You are learning about the virus and understanding why behaviors like staying $2 \mathrm{~m}$ apart and wearing face masks are necessary. This pandemic may also be a lesson about life: we may now have a greater appreciation that our lives are not solely governed by what is seen. The unseen can affect our lives in extremely dramatic ways! What can you do to stay safe? Wash your hands, wear a mask, and educate yourself and others! We are all in this together, so let us coordinate and work as a community.

\section{REFERENCES}

1. Wu, F., Zhao, S., Yu, B., Chen, Y. M., Wang, W., Song, Z. G., et al. 2020. A new coronavirus associated with human respiratory disease in China. Nature 579:265-9. doi: 10.1038/s41586-020-2008-3

2. Guzik, T. J., Mohiddin, S. A., Dimarco, A., Patel, V., Savvatis, K., Marelli-Berg, F. M., et al. 2020. COVID-19 and the cardiovascular system: implications for risk assessment, diagnosis, and treatment options. Cardiovasc. Res. 116:1666-87. doi: $10.1093 /$ cvr/cvaa106

3. Davis, R., and Hollis, T. 2016. Autoimmunity: why the body attacks itself. Front. Young Minds 4:23. doi: 10.3389/frym.2016.00023

4. Fuertes Marraco, S., Neubert, N., and Speiser, D. 2017. Good news from immunotherapy: our immune defense stands up to cancer. Front. Young Minds 5:40. doi: 10.3389/frym.2017.00040

5. Lundy, S. 2018. The immune system, in sickness $\&$ in health-part 1: microbes and vaccines. Front. Young Minds 6:49. doi: 10.3389/frym.2018.00049

SUBMITTED: 13 July 2020; ACCEPTED: 21 August 2020;

PUBLISHED ONLINE: 09 September 2020.

EDITED BY: Bahtiyar Yilmaz, Bern University Hospital, Switzerland

CITATION: Sabir SR, Thomson EC, Guzik TJ, D'Acquisto F and Maffia P (2020) COVID-19: The New Immune Challenge. Front. Young Minds 8:582971. doi: 10. 3389/frym.2020.582971

CONFLICT OF INTEREST: The authors declare that the research was conducted in the absence of any commercial or financial relationships that could be construed as a potential conflict of interest.

COPYRIGHT () 2020 Sabir, Thomson, Guzik, D'Acquisto and Maffia. This is an open-access article distributed under the terms of the Creative Commons Attribution License (CC BY). The use, distribution or reproduction in other forums is permitted, provided the original author(s) and the copyright owner(s) are credited and that the original publication in this journal is cited, in accordance with accepted academic practice. No use, distribution or reproduction is permitted which does not comply with these terms. 

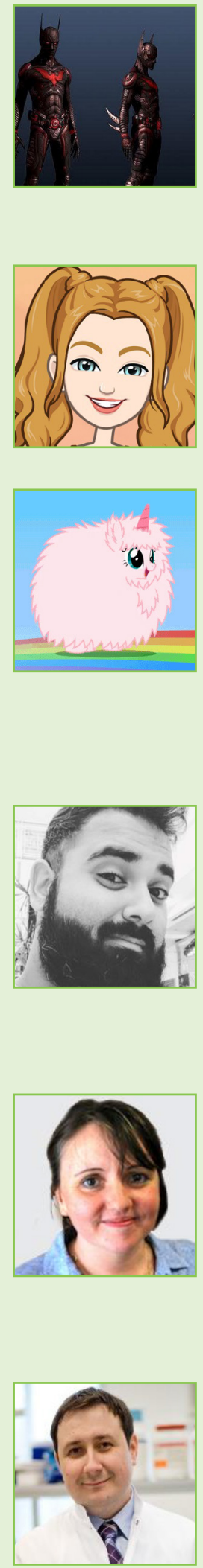

\section{YOUNG REVIEWERS}

\section{AYDEN, AGE: 12}

My name is Ayden, and my favorite subjects are History and English because we learn fascinating facts and read interesting books. I ran for my school's track team and came in fourth place out of 20 schools. I also enjoy spending time with friends and playing video games. I like playing golf and enjoy watching professionals play almost every weekend.

\section{LILI, AGE: 9}

$\mathrm{Hi}$, I like science and I am very interested in human illnesses. In my free time, I enjoy birdwatching, drawing, and painting.

\section{ZOE, AGE: 8}

My name is Zoe, and I will be in the second grade. My favorite hobby is dancing and have danced at the Joyce Theater in New York City. I love traveling and camping with my family. My favorite part about camping is roasting marshmallows! After a long day of school, I love hanging out with my 5 years old Welsh Terrier named Duke.

\section{AUTHORS}

\section{SULEMAN R. SABIR}

I am a third-year medical student at The University of Aberdeen currently working on COVID-19 wards as a phlebotomist. Having trained in medical science, I have a passion for public engagement. I enjoy communicating scientific concepts to the wider public. As part of this, I have developed several public engagement programs designed to inspire the next generation of scientists and encourage children to consider careers in science.

\section{EMMA C. THOMSON}

I am a professor of infectious diseases at the MRC-University of Glasgow Centre for Virus Research and the London School of Tropical Medicine and Hygiene. I use next-generation sequencing to identify new and emerging viruses both in the UK and in Uganda. I am currently working on projects to understand how the SARS-CoV-2 virus is evolving in the UK and on identification of viruses that threaten the well-being of healthcare workers and farmers in Uganda.

\section{TOMASZ J. GUZIK}

I am a Regius Professor of Physiology and Cardiovascular Pathobiology at the University of Glasgow, UK. I am a specialist in internal medicine, cardiology, and clinical immunology/allergy. As a physician scientist, I focus on research ranging from the discovery of new disease mechanisms to their applications to treat patients. My recent work included the discovery of the sources of free radicals in human vessels, the role of inflammation in hypertension, and more recently, the role of gum disease in high blood pressure. 


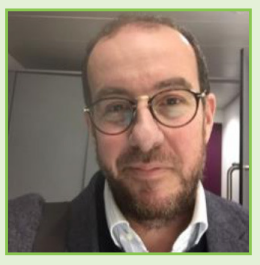

\section{FULVIO D'ACQUISTO}

I am a Professor of Immunology and Director of the Health Science Centre at the University of Roehampton in London. I have been the lead scientist and inventor for three patents and two licenses and have authored more than 100 publications in translational research. My current research interest is the investigation of the link between emotions, immunity, and inflammation (http:// www.affectiveimmunology.com). The overall aim of this new field of studies is to demonstrate the therapeutic potential of emotion-affecting immunomodulatory therapies and to foster new studies in this field.

\section{PASQUALE MAFFIA}

I am an Associate Professor of Immunology at the University of Glasgow, UK. I have a major interest in the immune response in cardiovascular disease. I am also strongly committed to outreach and science communication. As Specialty Chief Editor (Health) for Frontiers for Young Minds, I aim to engage young people in science and discovery, communicate the power of knowledge and creativity, cultivate the next generation of scientists, and encourage young people to become informed citizens. *pasquale.maffia@glasgow.ac.uk 